\title{
ユリノキの生育に及ぼす風の影響と支柱の効果に 関する実験的研究
}

An Experimental Study on the Effects of Wind and Propping on the Growth of Liriodendron tulipifera L.

海老根晶子* 藤井英二郎 ${ }^{* *}$ 三島孔明**

Akiko EBINE, Eijiro FUJII, Koumei MISHIMA

摘要 : 風が樹木の生育に及ぼす影響と支柱の効果について検討する目的で, ユリノキの 2 年生個体を
用い, 支柱をせずに風を当てた風区, 支柱をして風を当てた風・支柱区, 風を当てずに支柱をした支
柱区, 処理を加えない対照区の 4 区で地上部, 地下部の成長を比較した。その結果, 地上部では, 風
区で主幹と枝の節間の伸長成長, 支柱区で主幹の肥大成長が抑制される傾向が見られた。また, 風・
支柱区では, 成長が全体的に抑制されていた。

地下部については, 風区では風上側, 側面に比べ風下側で細根・中径根が抑制された。また, 支柱 区では支柱側よりも反対側で小径根が多くなった。これら 2 処理区に対し, 風・支柱区では方向によ る有意差は見られなかった。

\section{1. 研究の背景と目的}

多くの緑化樹では植え付けから活着に至るまで支柱は不可欠で ある。その一方, 植え付けてかなりの年数を経ていながら支柱が かかったまま放置されている実態がある。この状況について現場 の技術者からは, 必要以上の支柱はかえって根の発達を抑制して いるとの懸念も聞かれる。支柱が樹木の成長, とりわけ根系発達 によ゙のような影響を及ばすかについて計量的, 実証的に検討する ことは，造園技術として急がれる課題のひとつである。

樹木の摇れや倒伏の主要な要因は風であり, 支柱はその風に抗 する樹木の支持力を助ける屯のである。風が樹木の根に及ぼす影 響について, 根の直径の増加は指摘されてきた ${ }^{1)}$ が, 実験的に検 討した研究は少なかった。実験的に幼木に風を当てた研究 ${ }^{22,3)}$ は成長量の低下は報告されているが, 根系についての細かな検討 は為されていない。わずかに Stokes et al.は, 針葉樹を対象に した実験で, 風上側で太根数が増加することを報告している ${ }^{4)}$ 。 しかし，そこでは地上部成長との関係が検討されていない。

こうした風の影響に加えて, 支柱の有無と地上部・地下部の成 長の関係を実験的に検討した研究はこれまでのところ見られない。

以上のような技術的課題と既往研究の実態から, 本研究では風 および支柱の有無が樹木の地上部と地下部の生育に与える影響を 実験的に調べることとした。実験対象樹木としては, 街路樹や公 園樹として多用されているユリノキ (Liriodendron tulipifera L.）を選定した。ユリノキは主幹が明確であることから, 風や支 柱による成長の偏りが検討しやすいことも選定理由の 1 つである。

\section{2. 供試樹木と実験区の設定}

供試樹木としては, 後述するように市販の扇風機を使って風を 樹冠中心部に当てられることや, 地上部・地下部の調查が一定期 間に終了できる大きさの個体である必要から, ユリノキの 2 年生 個体とした。このユリノキの植付け時の樹高は $50 \mathrm{~cm}$ 前後, 根元 径は約 $0.5 \mathrm{~cm}$ であった。

2000 年 5 月上旬, 千葉県松戸市の千葉大学園芸学部内の実験 圃場に上記の樹木を植え付けた。具体的には, 根系調査が容易に なるよう直径 $120 \mathrm{~cm}$, 深さ $60 \mathrm{~cm}$ の不織布製コンテナを地中に据え 関東ロームを用土として植え付けた。その後，8月末まで一日 1 回の潅水を行い, 雑草と害虫は薬剤散布を使わず手取りとした。
実験区としては, 支柱をせずに風を当てる風区, 支柱をして風 を当てる風・支柱区, 風を当てずに支柱をする支柱区, 処理を加 えない対照区の 4 区を設定した。各実験区における個体数は 7 個 体ずつとした。なお, 各処理区間で植えつけ時の樹向に有意差は なかった。

扇風機による風の当て方としては, 次の 4 つの条件を考慮した。 (1)方向による影響を避けるため, 個体ごとに風を当てる方向を 変える。

(2)時間帯による影響を避けるため, 一日のうちで風を当てる時 間帯はランダムにする。

(3)風速は一定にし, 個体ごとに一定した方向から一定時間風を 当てる。

(4)風は，樹冠中心部に当てることとする。

風速は, 東京周辺の 7 月 -9 月の平均風速が $3.2 \mathrm{~m} \sim 3.5 \mathrm{~m} /$ 秒 であること ${ }^{5}$ から, 樹冠中心部での風速を $3 \mathrm{~m} /$ 秒とし, 扇風機 で風を当てた。この時, 扇風機から樹木までの距離は, $60 \mathrm{~cm}$ ( ンテナの半径) であった（写真 1 )。風は, 一日 2 時間ずっ当て ることとし, 風を当てる日は風区, 風・支柱区とも同一日とした。 風は, 2000 年 7 月中旬 -10 月上旬の晴天日 - 曇天日, 計 60 日当 てた。なお, 実験期間中の自然風のうち, 平均風速が本実験で負 荷した風速 $3 \mathrm{~m} /$ 秒を超えた日は，7月の 3 日間のみで，風向き はいずれむ南南西であった ${ }^{6)}$ 。

支柱は, 長さ $90 \mathrm{~cm}$, 直径 $1 \mathrm{~cm}$ の支柱を地中に $50 \mathrm{~cm}$ 入れ込み, 地上部 $40 \mathrm{~cm}$ 幹に沿わせる形の添木支柱とした。支柱は, 風・

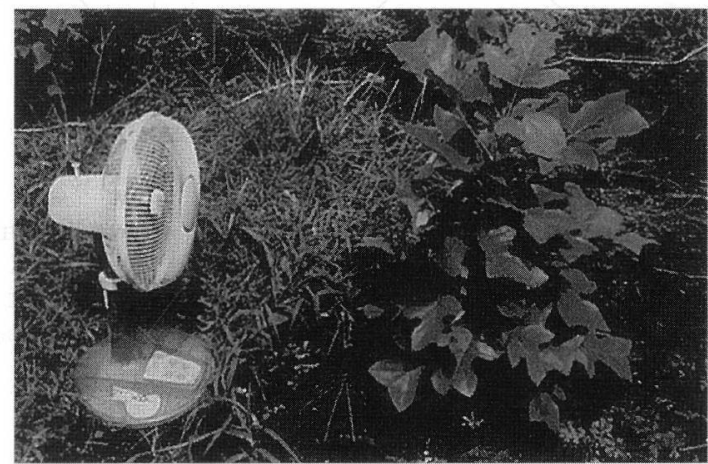

写真 -1 風を当てる様子 
支柱区については風処理を始める直前の 7 月中旬に幹の風下側に 添わせた。また支柱区についても同じ生育条件下とするために， 同時期に支柱を施した。

各個体の配置については, 風以外の環境条件による差が出ない ように，実験区ごとにまとめずランダムに配置した（図 1 )。

\section{3. 調查項目}

樹木地上部の測定項目は, 根元径, 主幹長, 枝伸長量, 幹乾重, 枝乾重, 葉数, 葉面積, 葉乾重とした。根元径, 主幹長, 枝伸長 量, 葉数は 2000 年 7 月上旬 -10 月上旬に月 1 回測定した。葉面 積, 葉乾重は落葉直前の 10 月に测定した。上記の項目の測定は, 対照区で 2 個体が枯損したため, 各処理区 5 個体ずつについて行っ た（図 1 で*のついている個体)。幹乾重, 枝乾重は, 後述する 根系調査個体について計測した。

樹木地下部については, 2000 年 11 月上旬一 2001 年 3 月中旬に 各実験区 3 個体ずつ根系を全量調査した。この全量測定法では, 根系全体を風区，風・支柱区では風上側，風下側，両側面に，ま た支柱区では支柱側，支柱の反対側，両側面に，そして対照区で は東西南北にそれぞれ 4 分割した後, 幹を中心に半径 $20,40 \mathrm{~cm}$ の同心円状に細分割して調査を行った。垂直方向については，10 $\mathrm{cm}$ 毎に分割した。根は, 上記のブロック毎に, 直徍によって中径 根 $(0.5 \sim 2 \mathrm{~cm})$, 小径根 $(0.2 \sim 0.5 \mathrm{~cm})$, 細根 $(0.2 \mathrm{~cm}$ 以下) に区 分し乾重を測定した。

\section{4. 結果及び考察}

\section{(1) 樹木地上部}

\section{(i ) 根元径}

2000 年 5-10月の根元径成長量について (四 2), 繰り返しの ある二元配置の分散分析を行った結果, 風処理については有意差 がなかったが, 支柱処理の有無に関しては有意差がみられた

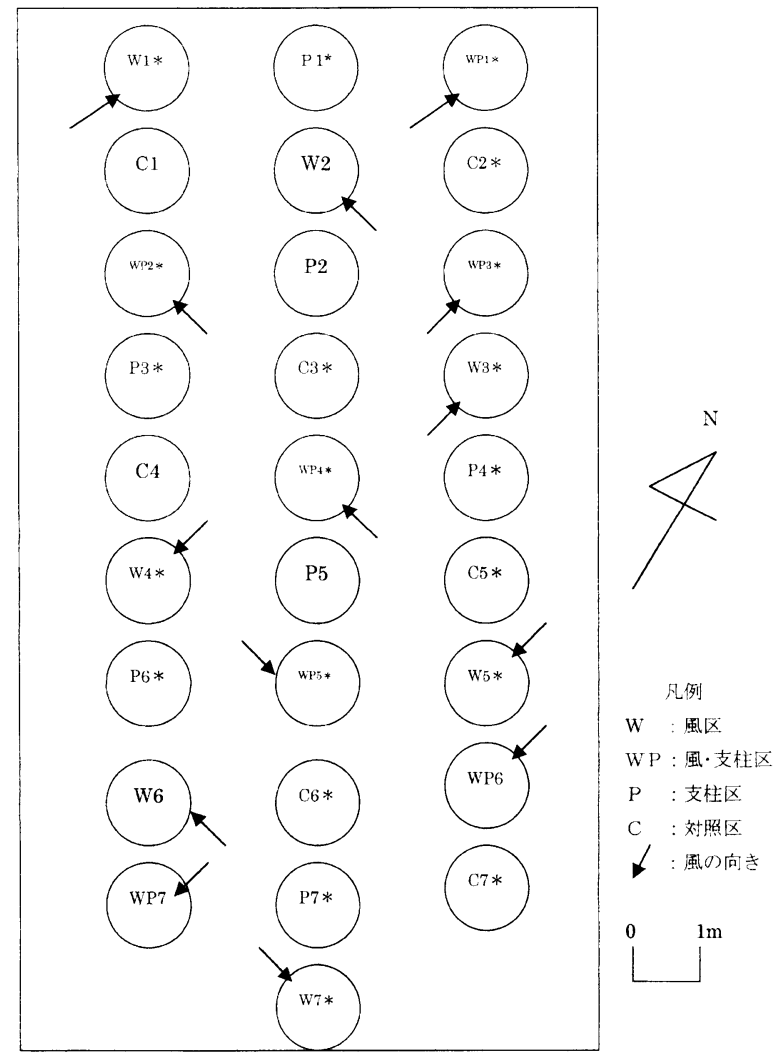

図-1 実験区と各個体の配置
$\left(\mathrm{F}_{0}=9.8, \quad \mathrm{P}=0.06\right)$ 。つまり, 風負荷の有無にかかわらず支柱に よって根元径成長は抑制されたといえる。

(ii) 主幹長

2000 年 5-10月の主幹長伸長量について (図 3), 繰り返しの ある二元配置の分散分析を行なったところ，支柱処理の有無では 有意差は見られなかったが，風処理の有無については有意差が見 られた $\left(\mathrm{F}_{0}=3.6, \mathrm{P}=0.08\right)$ 。このことから, 風の負荷によって 幹の伸長が抑制される傾向があるといえる。

(iii) 枝

2000 年 5-10月の枝伸長量について (図 4), 繰り返しのある 二元配置の分散分析を行なったところ，有意差は見られなかった。 また，上記伸長枝の平均節間長（葉と葉の着生位置間の距離）を 実験区間で比較すると（図 5 ), 実験区内の個体差は大きいもの の, 繰り返しのある二元配置の分散分析の結果, 風処理の有無に 関して有意差が見られた $\left(\mathrm{F}_{0}=4.1, \mathrm{P}=0.06\right)$ 。これより, 風に よって枝の節間長が短くなる傾向があるといえる。つまり，本実 験で負荷した風は枝の伸長量には影響を及ぼさないが，枝の節間 長には影響を及ぼし，節間を詰めることが分かる。

(iv) 葉

2000 年 11 月時点における各個体の平均総葉乾重を, 繰り返し のある二元配置の分散分析によって実験区間で比較したが（図 6 ）， 有意差はなかった。同様に，葉 1 枚あたりの乾重を比較したが (図 7), 有意差はなかった。

2000 年 11 月時点の各実験区の平均葉面積について（図 8 ）, 繰り返しのある二元配置の分散分析を行ったところ，風処理では 有意差は見られなかったが, 支柱の有無については有意差が見ら れた（ $\left.\mathrm{F}_{0}=4.3 ， \mathrm{P}=0.05\right)$ 。つまり，風処理の有無に関わらず， 支柱によって葉面積が小さくなり，葉の成長が抑制されるといえ る。

\section{（v）枝と葉の関係}

葉面積を測定した枝について，平均節間長と平均葉面積の比（= 平均葉面積/平均節間長) を求め, 実験区間で比較すると（図 9 ), 風・支柱区と支柱区で值が小さい傾向が見られた。そこで, 繰り 返しのある二元配置の分散分析を行なったところ，支柱処理の有

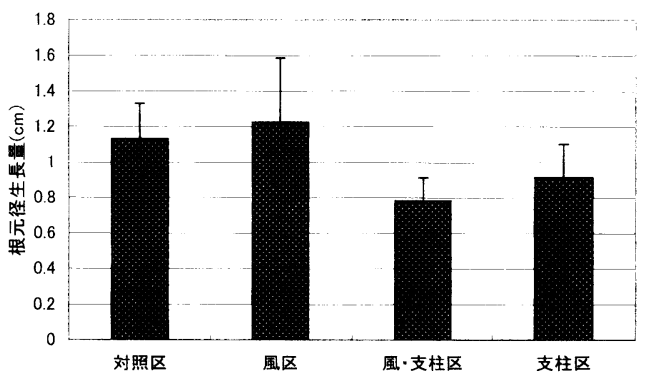

図-2＼cjkstart処理区ごとの平均根元径生長量 (値は平均値十標準偏差)

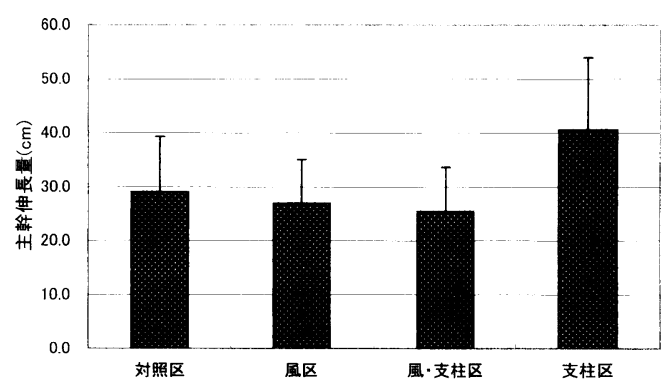

図-3＼cjkstart処理区ごとの平均主幹長伸長量 (値は平均値＋標準偏差) 
無に関して有意差が見られた（ $\mathrm{F}_{0}=7.8 ， \mathrm{P}=0.01 ）$ すなおち， 支柱をした実験区では，支柱をしなかった実験区に比へて節間長 の割に葉面積が小さかったことを示している。つまり，風処理の 有無に関わらず，支柱によって節間伸長に比して葉の成長が抑制 されるといえる。

\section{(2) 樹木地下部}

\section{(i ) 根系全体の乾重}

各処理区 3 個体ずつ根系全体の乾重を測定した。但し, 対照区 3 個体のうち 2 個体については, 全体の 4 分の 1 の部分について 調査したので，值を 4 倍した。繰り返しのある二元配置の分散分 析によって乾重を処理区間で比較したところ(図 10)，処理区間 に有意差はなかった。つまり, 風や支柱の有無は全根乾重には影 響を及ぼさないといえる。

次に太さ区分ごとに根の乾重を処理区間で比較したところ（図 11), 細根, 小径根, 中径根のいずれにおいても, 風・支柱区の 值が低い傾向が見られた。そこで繰り返しのある二元配置の分散 分析を行なったところ, 細根, 小径根については処理区間に有意 差がなかったが，中径根については風の有無に関して危険率 $6 \%$ で有意な差が見られた。つまり, 風は根系のなかでも特に中径根 の発達に対して影響を及ぼす傾向があるといえる。

（ii）風及び支柱による根乾重の方向別比較

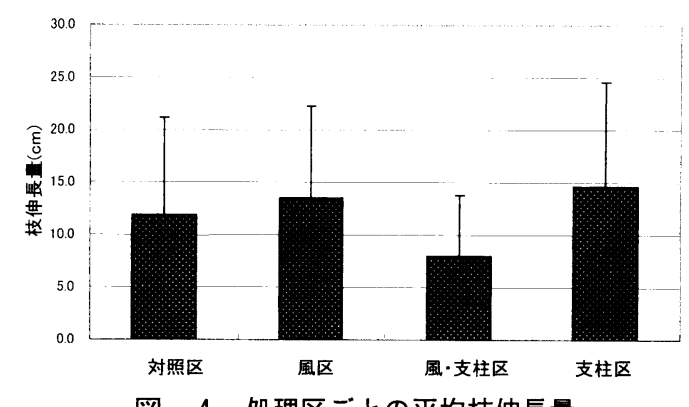

図一 4 処理区ごとの平均枝伸長量 (値は平均値十標準偏差)
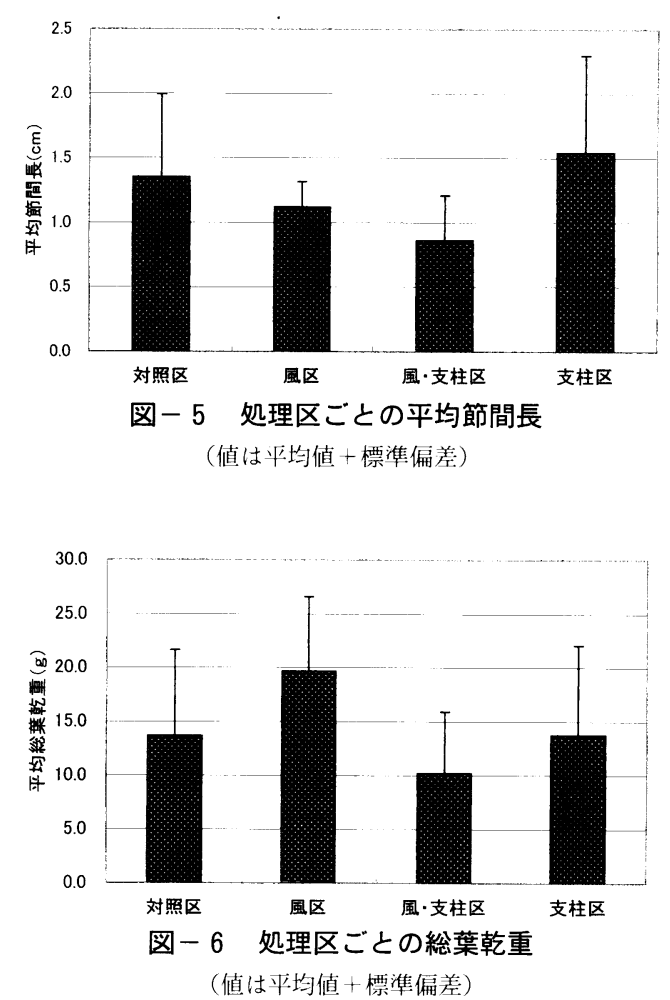

風と支柱が根系に及ぼす影響を詳しく把握するために, 各処理 区ごとに細根, 小径根, 中径根の乾重と方向による違いを検討し た。方向は, 風区, 風・支柱区では風上側・側面・風下側, 支柱 区では支柱側・側面・反対側とした。なお，側面は個体ごとに 2 区画あるので, それらの平均值を用いた。また対照区については, 調査した 3 個体のうち 2 個体は根系全体の 4 分の 1 の部分を調查 し， 1 個体は根系全体を東・西・南・北の区画に分けて調查した ので, 根采全体を調査した 1 個体については，4 方位の平均值を 用いた。

各処理区ごとの方向別乾重の平均值は図 12 のとおりである。 各処理区内の比較には, 繰り返しのない二元配置の分散分析で方 向間の差を検定し，その後ダンカンの多重比較を行なった。また， 各方向之対照区との比較には，ダネットの多重比較を用いた。

その結果, 風区については, 細根で有意差が見られ $\left(\mathrm{F}_{0}=18.4\right.$, $\mathrm{P}=0.009)$, 風上が側面, 風下より有意に高い值を示し, 側面も 風下より有意に高い值を示していた。対照区と比べると, 有意差 は見られないものの，風上側のほうが高い傾向が見られた。また， 中径根でも有意差が見られ $\left(\mathrm{F}_{0}=5.0, \mathrm{P}=0.042\right)$, 風下側が風上 側, 側面より有意に低い值を示し, 対照区と比べても風下側が有 意に低い值を示していた。

支柱区については，小径根で有意差が見られ（ $F_{0}=6.6, \quad P=$

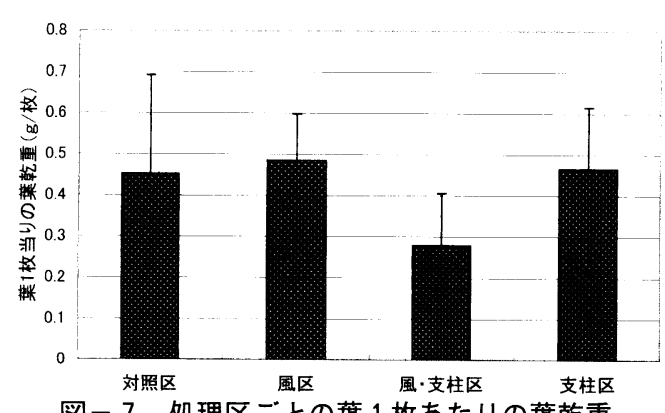

図-7 処理区ごとの葉 1 枚あたりの葉乾重

(值は平均値＋標準偏差)

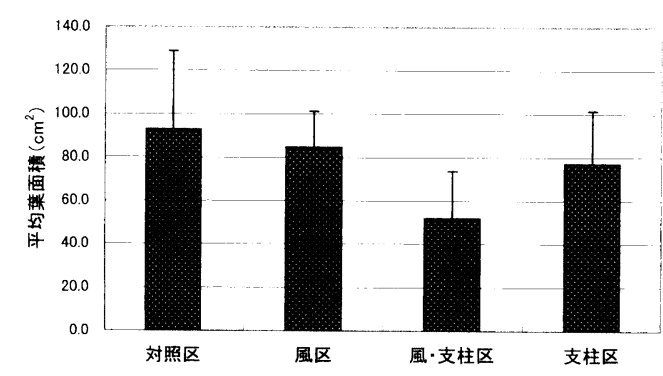

図 -8 処理区ごとの平均葉面積

(值は平均值 + 標準偏差)

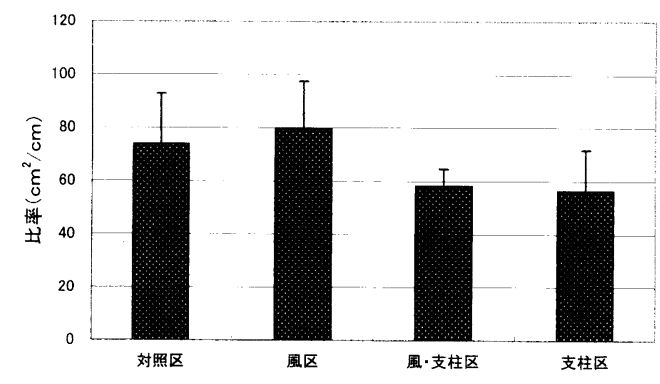

図-9 処理区ごとの節間長と葉面積の比率 (値は平均値+標準偏差) 

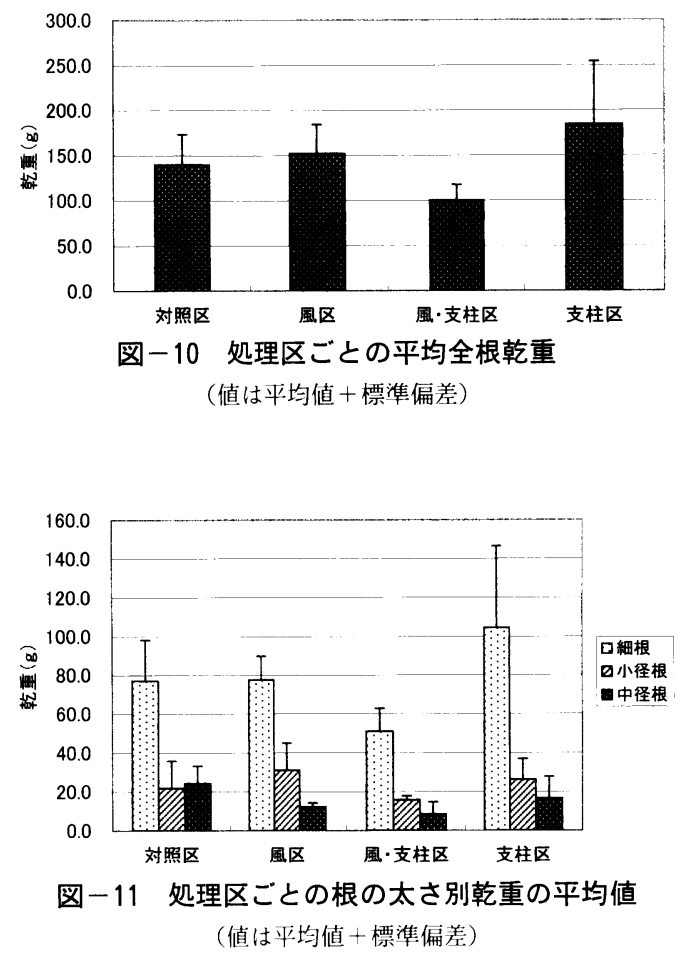

0.054), 反対側の方が支柱側よりも有意に高い值を示し, 対照区 と比べると, 有意差は見られないものの反刘側のほうが高い傾向 が見られた。しかし, 細根之中径根には有意差は見られなかった。 このことから, 支柱区では, 支柱の位置によって小径根の分布が 变化するが, 細根・中径根では方向による違いは見られないとい える。

また，風・支柱区については，どの太さの根についても方向に よる有意差は見られなかった。このことから，風と支柱を併せて 処理した場合には，特に根の分布に影響を及ぼさないといえる。

以上の結果より，風区では風上側，側面に比へ，風下側におけ る細根之中径根の発根が抑制されているといえる。また, 対照区 と比較すると, 風下側で中径根の発根が抑制されるといえる。こ のことから, 樹木に風があたる場合, 風下側では, 通常の生育に 比へ，支持機能の大きい中径根ばかりでなく養水分吸収に大きな

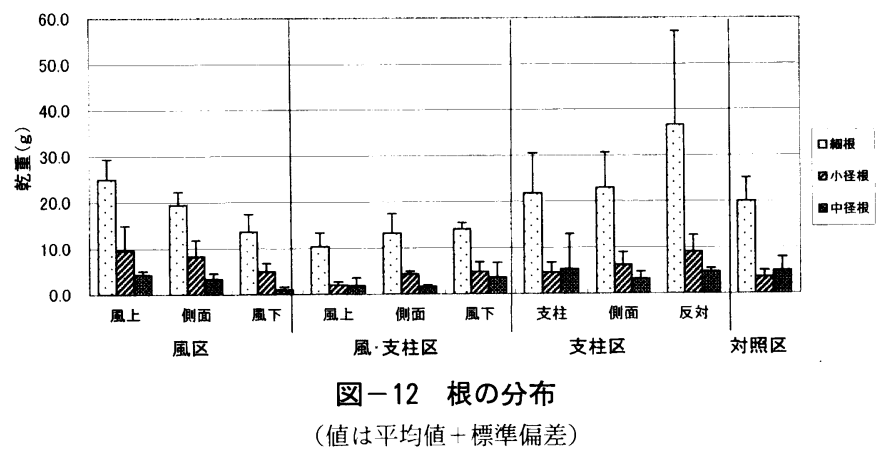

役割を果たす細根の発根む抑制されるということを示唆している と考えられる。

支柱区では，反対側に比べ支柱側で小径根の発根が抑制されて いるといえる。このことから，樹木に添え木支柱をした場合，そ れが当てられた側の小径根の発根は抑制されるが, 細根・中径根 は支柱の影響を受けないということを示唆していると推測される。

上記 2 区の結果を踏まえると，風・支柱区の根において方向に よる明確な偏りが見られなかったことは，風が樹木に及ぼす力と 支柱の樹木を支持する力のバランスが取れて㧈り，風向きに応じ て根の分布を変化させなくても樹木を支持できていたことを示唆 していると推測される。

\section{5.おわりに}

今回の実験により，ュリノキの幼木に風を当てると，地上部に おいては主幹と枝の伸長を抑制する傾向があることが検証された。 また，地下部では，風の影響によって風下側の細根と中径根の発 根が他の方向に比べて抑制されることが明らかになった。

次に，支柱を掛けた場合には，根元径の肥大生長が抑制される 一方で, 幹の伸長生長が旺盛になった。また，支柱を掛けたこと で葉面積が小さくなり, 葉の生育はあまり良好ではなかった。地 下部では, 支柱の反対側に比べ支柱側で小径根の発根が抑制され ていることが明らかとなった。

支柱を掛け，風を当てた場合には，地上部の成長が全体的に抑 制されていた。地下部では方向による根の偏りは見られず, 支柱 の支持力と風の影響力のバランスが取れていることが示唆されて いると推測される。

\section{引用文献}

1) Wilson, B.F (1975): Distribution of secondary thickening in tree root systems. In The Development and Function of Roots,ed.J.G. Torrey \& D.T.Clarkson,pp.197-219.Academic Press, New York

2) Satoo, $T$ (1962): Wind,transpiration and tree growth .In Tree Growth,
ed.T.T.Kozlowski,pp.299-310.Ronald Press, New York.

3) Heiligmann,R.\& Schneider,G (19 74): Effects of Wind and soil moisture on black walnut seedlings .Forest Science,20,331-5.

$4)$ Stokes.A,A.H.Fitter,M.P.Coutts (1995): Responses of young trees to wind: effects on root growth (Wind and Trees, Edited by M.P.Coutts and J.Grace),pp264-275. Cambridge University Press, Cambridge.

5 ）気像庁（1997）: 気象月報 1997 年 7 , 8,9 月: 財団法人気像業務支援セン 夕一, 1

6 ）父像庁（2000）: 気像月報 2000 年 7 , $8,9,10$ 月 : 財団法人気象業務支援七 ンター, CD-ROM

Summary: The purpose of this experiment is to clarify the influence of wind and propping on growth of 2-year-old tulip tree (Liriodendron tulipifera L.). To compare the tree growth, we set up four kinds of section (1)Wind, (2)Wind and Propping, (3) Propping, (4)Control). As a result, the growth of a trunk and a branch were controlled in the wind section. In the propping section, the enlarge growth of a trunk were controlled. On the other hand in the wind and propping section, the growth of trunk and branch was prevented in general. About the root system, there were more roots in the windward side in the wind section. And in the propping section, there were more roots at the opposite side to the prop. Comparing with these two sections, the root volume in the wind and propping section was districted in all directions. 